\title{
Language Related Research
}

E-ISSN: 2383-0816

https://lrr.modares.ac.ir

https://doi.org/10.21859/LRR.11.5.125

Vol. 11, No. 5

pp. 125-144

November \&

December

2020

\section{Students' Perceptions of the English Literature Component in Malaysian Secondary Schools}

\author{
Engku Suhaimi Engku Atek ${ }^{1}$ (D) Isyaku Hassan $2^{*}$ (iD), Mohd Nazri Latiff Azmi ${ }^{3}$ iD, \\ Nor Jijidiana Azmi ${ }^{4}$ iD, \& Mohd Hazlli Yah Alias ${ }^{5}$ iD
}

\begin{abstract}
Students' understanding of literature is often neglected, while curriculums are usually determined by educationists whose expectations might not suit the students' ability. To achieve a positive learning outcome in the literature classroom, the students' perceptions and interests must be accorded much consideration. Therefore, this study aims to determine students' perceptions of the importance of the English literature component in selected secondary schools in Terengganu, Malaysia. The study employed a descriptive survey method in which a structured questionnaire was used as a data-gathering instrument. The data were gathered from a sample of 403 students across four different public secondary schools in Terengganu: SMK Kompleks Seberang Takir, SM Sains Sultan Mahmud, SMKA Dato Haji Abbas, and SMK Kompleks Gong Badak. The study found that the students have positive perceptions of the English literature component to a large extent. The students also believe that English literature enables them to develop their cultural awareness, critical thinking skills, as well as improve their English grammar and vocabulary. The moral-philosophical approach is the most preferred approach amongst the students, followed by the information-based approach and the language-based approach. It is envisaged that the findings of this study could be especially useful in the process of curriculum development, particularly in the Malaysian context. Besides, this study could raise teachers' awareness of their students' level of understanding of the English literature component.
\end{abstract}

Keywords: descriptive survey, English literature, ESL classroom,

1. MA, Faculty of Languages and Communication, Universiti Sultan Zainal Abidin, Malaysia; ORCID ID: https://orcid.org/0000000248892904

2. Corresponding Author, PhD, Postdoctoral Researcher, Faculty of Languages and Communication, Universiti Sultan Zainal Abidin, Malaysia; Email: isyaku87@gmail.com;

ORCID ID: https://orcid.org/0000000282602894

3. PhD, Associate Professor of English Language, Faculty of Languages and Communication, Universiti Sultan Zainal Abidinm, Malaysia; ORCID ID: https://orcid.org/0000000247125332

4. MA, Faculty of Languages and Communication, Universiti Sultan Zainal Abidin, Malaysia; ORCID ID: https://orcid.org/0000000179227993

5. MA, Faculty of Languages and Communication, Universiti Sultan Zainal Abidin, Malaysia; ORCID ID: https://orcid.org/000000033984780X 


\section{Introduction}

English literature is accepted as a means of developing and improving language proficiency (Hişmanoğlu, 2005; Keshavarzi, 2012; Mustafa et al., 2020; Paran, 2008; Simpson, 2003). The learning of English literature shapes the learners' personality and self-awareness through communication with the literary texts and advances their enthusiasm and comprehension of the world around them (Cheng, 2016). According to Van (2009), English literature develops students' language skills and cultural awareness, as well as encourages their critical thinking. Therefore, English literature plays an educational, recreational, moral, cultural, and socio-political role in the learning environment (Azmi et al., 2020a; Ihejirika, 2014; Mahzan et al., 2020).

In 2000, the literature component was incorporated into the English syllabus in Malaysian secondary schools (Ghazali et al., 2009). Until today, this literature component program attracts the attention of researchers, teachers, and policymakers (Ahmad \& Aziz, 2009; Bridget \& Omar, 2007; Hwang \& Embi, 2007; Krishnasamy, 2015). The literature component aims to develop affection for literature in the students' mindsets and equip them with an in-depth understanding of English literature (Subramaniam, 2007). The syllabus incorporates various literary texts including short stories, novels, poems, and drama. In this regard, the Ministry of Education specified that the students should have the ability to critically evaluate the characters, settings, plots, and the author's viewpoints as well as other artistic components in literary texts.

According to Åkerlind (2008), a student-centered approach is considered more important than a teacher-centered approach. As such, students' perceptions and interests must be accorded much consideration to achieve a positive learning outcome in the literature classroom (Åkerlind, 2008; Candlin \& Mercer, 2001; Sidhu, 2003). Students' perceptions could enrich the learning environment by advancing our understanding of the teaching and learning process (Carroli, 2002). This argument concurs with the phenomenographic supposition that focusing on students' ability is crucial in developing positive learning experiences (Booth, 2008; Dahlin, 2007), and hence, this study takes a phenomenographic perspective. This perspective could provide a rational argument for why students' perceptions of the literature component are imperative.

Despite the importance of the student-centered approach in achieving positive 
learning outcomes (Booth, 2008; Dahlin, 2007; Sidhu, 2003), very few studies investigated the students' perceptions of the literature component (Carroli, 2002; Naser \& Aziz, 2017; Othman et al., 2015; Tseng, 2010), focusing on text preferences, reading interests, and challenges faced by the students. Therefore, this study aims to explore students' perceptions of the English literature component and ascertain their preferences for the literature teaching approaches in selected Malaysian secondary schools. Specifically, this study aims to address the following research questions.

1. What are the students' perceptions of the importance of the English literature component in the selected secondary schools?

2. What are the most preferred English literature teaching approaches among students in the selected secondary schools?

\section{Literature Review}

A few studies investigated the students' perceptions of English literature in the ESL classroom with different dimensions and research designs (Carroli, 2002; Mustafa et al., 2020; Naser \& Aziz, 2017; Othman et al., 2015; Tseng, 2010). Most of these studies demonstrated the importance of considering students' perceptions in the literature teaching process. For example, Carroli (2002) investigated the perceptions of literature among students in Italy and Australia. The study concluded that students' perceptions of literature should be fundamental in text selection and pedagogical practices. Therefore, to achieve a positive learning outcome in the literature classroom, the students' perceptions and interests must be accorded much consideration (Naser \& Aziz, 2017; Othman et al., 2015; Sidhu, 2003; Tseng; 2010).

Furthermore, Othman et al. (2015) examined students' perceptions and challenges concerning English literature learning in Selangor, Malaysia. The study found that the majority of the students have positive perceptions of literary texts. Similarly, Mustafa et al. (2020) found that ESL learners have positive attitudes towards learning literature and its methods of teaching. According to these findings, students' positive perception of literature could help teachers and educationists in developing an effective curriculum and teaching strategies (Othman et al., 2015). However, students' attitudes toward literature are often 
neglected and curriculums are usually determined by educationists whose expectations might not suit the students' ability (Tseng, 2010). According to Othman et al. (2015), leaning outcome in the literature classroom is dependent upon the students' perceptions toward the integration of literature in the ESL classroom.

Additionally, students have different interests across various literary genres. In this regard, Naser and Aziz (2017) found that students were more interested in plots of the texts rather than the type of literature used, while Tseng (2010) reported that students like novels most, followed by plays and short stories. Nevertheless, there has been little attention to the students' perceptions of literature learning (Carroli, 2002; Naser \& Aziz, 2017). Therefore, this study focuses on the importance of students' perceptions of English literature subjects, particularly in secondary schools. In essence, students' responses are paramount in the teaching and learning process (Ahmad \& Aziz, 2009; Carroli, 2002; Sidhu, 2003).

\subsection{Issues in the English Literature Classroom}

The learning of English literature constitutes part of cultural knowledge acquisition and not merely language administration (Kow, 2002; Zengin et al., 2019). It encompasses self-motivation and a high level of enthusiasm towards reading, knowledge acquisition, social customs, and values in everyday life. Nevertheless, students and teachers of English Literature experience various issues in the learning and teaching process, respectively. For example, Kow (2002) noted that teachers without an adequate level of experience may be confused in choosing an approach and may eventually confuse the students. Besides, teachers who have a class of weak students may generally adopt an easier approach, and to help these weak students pass their exams, teachers tend to focus on teaching how to answer past question papers. In this situation, the students may score high marks in exams while ignoring the main purpose of knowledge acquisition.

Furthermore, lack of good reading materials might cause difficulties in the English literature classroom (Azmi et al., 2020b; Ghazali et al., 2009). For instance, when there is an inadequate number of books for students, instructors force students to use photocopies. Consequently, the students become less 
interested to participate in class activities because the photocopied books are not easy to read like the original copies (Mustakim et al., 2015). According to Savvidou (2004), teachers, course designers, and examiners are often reluctant to introduce unedited and genuine literary texts to the language program. This issue could be further augmented by the students' limited proficiency, and hence results in the use of the mother tongue for interpretations in the classroom.

Moreover, language facilities provided by school managements are often utilized maximally. In this situation, instructors are required to be imaginative and inventive to organize attractive classroom activities (Mahzan et al., 2020). The hidden messages contained in literary texts and their relevance must be considered as a fundamental criterion in choosing an appropriate literary text for use in the second language classroom (Hişmanoğlu, 2005). Other problems include inappropriate text selection, learners' language anxiety, cultural misperceptions, and poor background knowledge (Alshammari et al., 2020; Zengin et al., 2019).

The above issues must be addressed to facilitate the English literature learning process, particularly in second language classrooms. This is because English literature is recognized as a mechanism of English language learning (Sarac, 2003), as it plays educational, moral, cultural, recreational, and socio-political roles in the English learning process (Ihejirika, 2014; Mustafa et al., 2020). English literature enhances the students' social and language abilities in the language classroom. Besides, exposure to good English literature could facilitate self-identity formation among students (Azmi et al., 2020a; Ogunnaike, 2002; Velu, 2010). This is because, through English literature, students are exposed to various skills that are crucial for the development of desirable morals. English literature involves a more complex usage of language.

Part of the objectives of the literature is to instill a passion for reading. This can only be truly achieved if the students can acknowledge the value of English literature beyond the textbooks (Kow, 2002). Therefore, the passion for reading must be underscored, and at the same time, students must be prepared to acquire knowledge through reading. Literature teaching and learning in Malaysia's education system, at both primary and secondary levels, are recognized as an instrument for the development of basic language skills (Hişmanoğlu, 2005). In Malaysia, the development of English literature as a component of the English Language is seen as an important project in the educational sector (Rashid et al., 
2010).

In sum, issues in English literature classrooms include improper choice of approach, focus on how to answer the past question papers, lack of good reading materials, students' limited proficiency, and at times, lack of experience among teachers themselves. Students also need a good grasp of the target language to appreciate choices and deviances in the text (Ghazali et al., 2009). Learning consists of knowledge acquisition particularly through skills and guidance. Ghalazli et al. (2009) noted that students' low proficiency levels prevented teachers from using student-centered techniques such as debates and group discussions. Instead, instructors use a teacher-centered approach to save time and prepare for examinations.

\subsection{Approaches to the Teaching of English Literature}

According to Carter and Long (1991), there are three models of teaching literature: 1) the cultural model, which requires learners to explore and interpret the social, political, literary and historical context of a specific text; 2) the language model, which enables learners to access a text systematically and methodically to exemplify specific linguistic features such as literal and figurative language, direct and indirect speech; 3) the personal growth model, which focuses on the particular use of language in a text as well as placing it in a specific cultural context (Carter \& Long, 1991; Mustakim et al., 2014; Rashid et al., 2010). These three models of teaching literature have been integrated into the following approaches: 1) information-based approach, where literature is seen as a means of offering a source of information to learners; 2) paraphrastic approach, where teachers use simpler words and sentence structures compared to the complicated ones in the literary texts; 3) stylistic approach, which guides learners toward a closer comprehension of the literary texts; 4) language-based approach, which represents an approach where literary texts are viewed as a means of helping learners to develop language skills; 5) personal-response approach, which focuses on the learner's response to the literary text; 6) moral-philosophical approach, which enables teachers to incorporate moral values in their lessons (Rashid et al., 2010).

Previous studies confirmed that teaching approaches are largely influenced by students' language proficiency, and these approaches offer a great opportunity for 
students to develop language proficiency and enhance their level of involvement in the learning process (Bridget \& Omar, 2007; Hwang \& Embi, 2007; Rashid et al., 2010. For instance, Rashid et al. (2010) identified the approaches and strategies employed by teachers in teaching the literature component to less proficient students in Malaysia. The study found that the information-based approach is popularly employed by teachers, followed by the moral-philosophical approach and paraphrastic approach. The findings indicate that the teaching approach is influenced by the students' inability to comprehend the English language. In this regard, Hwang and Embi (2007) noted that teaching approaches are largely influenced by students' language proficiency and attitudes. Similar to the findings of Rashid et al. (2010), Bridget and Omar (2007) found that the moral-philosophical approach was the most preferred approach amongst teachers of English literature. Hwang and Embi (2007) also examined the approaches employed by teachers in teaching the literature component in selected Malaysian secondary schools. The study showed that the paraphrastic approach is popularly used by teachers, followed by the information-based approach and the moralphilosophical approach.

\subsection{Theoretical Approach}

This study focuses on literature learning from the students' perspective, and therefore, the arguments are guided by phenomenography as a theory (Booth, 2008; Carroli, 2002). Phenomenography developed from a series of empirical studies conducted by a Swedish research group in the 1970s (Bussey et al., 2013; Dahlin, 2007; Runesson, 2005). The central theoretical principle of phenomenography presumes that student-centered understanding is more sophisticated because it is more complex than teacher-centered understanding (Åkerlind, 2008). According to Åkerlind (2008), learning outcomes are attributed to the student's ability, motivation, and attention. Though this study was carried out through a deductive approach, phenomenography could be relevant because, as a theory, its theoretical background is rooted in the general scientific tradition not some specific schools of thought (Svensson, 1997).

Subsequently, grounded in phenomenographic research, a theory of learning known as variation theory was developed (Marton \& Booth, 1997; Marton \& 
Tsui, 2002). This theory is viewed as a more theoretical extension of phenomenography (Bussey et al., 2013; Tan, 2009). In variation theory, the central focus is the object of learning and its manifestation through the intended, enacted, and lived objects of learning (Bussey et al., 2013). The object of learning is the main focus of research as well as the most significant aspect of understanding classroom activities and determining the learning outcomes (Runesson, 2005). Based on the above theoretical concepts, students' perceptions of English literature could be a key determinant of learning outcomes in the literature classroom.

\section{Methodology}

This study employed a quantitative approach in which a descriptive survey method was used. Survey designs generalize results from a sample to a population and therefore allow for strong and valid conclusions (Allen et al., 2009; Creswell, 2012). Besides, surveys provide useful information to describe trends about a large number of people (Creswell, 2012). Therefore, a questionnaire was used in this study due to its ability to gather easily quantified data within a short possible time. A questionnaire is considered as an objective research instrument that can produce generalizable results (James, 2012).

\subsection{Data Collection}

This study was limited to English language students selected from four different public secondary schools in the State of Terengganu, Malaysia: SMK Kompleks Seberang Takir, SM Sains Sultan Mahmud, SMKA Dato Haji Abbas, and SMK Kompleks Gong Badak. The literature component is offered from Form One until Form Five. Hence, the target population of this study consists of Form Four students in the selected schools as they have been learning English literature for more than three years. Thus, this group of students could be considered a good sample as they can share their experiences regarding the approaches employed by their teachers in teaching English literature. Simple random sampling was used to select a sample of 420 students from the selected schools. Random sampling refers to a method of sample selection that gives each element in the population an equal probability of being selected and included in the sample (Kothari, 2004). The sample was estimated using Krejcie and Morgan's (1970) formula for sample size calculation. 
A structured questionnaire was used as a data-gathering instrument. The questionnaire used in a study conducted by Rashid et al. (2010) was adopted and modified. The items in the questionnaire were formed using a five-point Likert scale (Lois \& Gavin, 2010), consisting of 28 items. The questionnaire was administered to the randomly selected sample of 420 students across the selected secondary schools. The main objective was to gather information about English literature approaches preferred by the students in learning the English literature subjects. In the process of distributing the questionnaire, the students were guided on how to respond to the questions.

\subsection{Data Analysis}

The data were analyzed using descriptive statistics, consisting of mean, standard deviation, frequency, and percentage (James, 2012). To ensure reliability, a pilot study was conducted using a sample of 30 respondents to determine if the questions would yield the desired information necessary for the study and to avoid inappropriate, misleading, and redundant questions. A Cronbach's Alpha of .922 was obtained, which is within the acceptable range (0.70-0.95) of statistical values (Tavakol \& Dennick, 2011). The descriptive statistics used in this study were calculated using the SPSS statistical software package (SPSS Inc., Chicago, IL, USA, 20.0).

\section{Results}

This study was set to determine students' perceptions of the importance of the English literature component in selected secondary schools in Terengganu, Malaysia. Altogether, 420 questionnaires were administered across the selected secondary schools. Out of this number of questionnaires, 409 were returned, representing a high response rate of 97.4 percent. Besides, six questionnaires were rejected during analysis due to incomplete and invalid responses. Therefore, a total of 403 questionnaires were considered for analysis. The majority (58.8\%) of the students are females, while $41.2 \%$ are males. Besides, the majority of the students $(91.8 \%)$ were 16 years of age, $7.2 \%$ were above 16 , while only $1.0 \%$ were 15 years old. A sizeable number (97.0\%) of the students are Malays while Chinese, Indians, and other ethnic groups constitute $1.0 \%$ respectively. 
In the descriptive statistics, A+SA represents a combination of "Agree" and "Strongly Agree" responses as specified in the questionnaire. It was used to show the frequency of students who agree with the statements provided in the questionnaire. Besides, D+SD represents "Disagree" and "Strongly Disagree" which was used to show the frequency of students who disagree with the statements. Similarly, N stands for "Neutral" and was used to show the frequency of students who neither agree nor disagree with the statements. Since the fivepoint Likert scale suggests that "5" represents the highest mean value, the values of each construct are reported within the range of 0.00 and 5.00. RQ1 aims to determine the students' perceptions of the importance of the English literature component in the selected secondary schools. Table 1 shows the descriptive statistics for the students' perceptions of the English Literature component.

Table 1

Students' perceptions of English Literature

\begin{tabular}{|c|c|c|c|c|c|c|}
\hline \multirow[t]{2}{*}{ SN } & \multirow[t]{2}{*}{ Statement } & \multicolumn{5}{|c|}{ Total $(\mathrm{F} / \%)$} \\
\hline & & Mean & SD & $\mathrm{A}+\mathrm{SA}$ & $\mathrm{D}+\mathrm{SD}$ & $\mathrm{N}$ \\
\hline 1 & $\begin{array}{l}\text { By reading the literary texts, I } \\
\text { can improve my vocabulary, } \\
\text { grammar, and pronunciation }\end{array}$ & 3.90 & .806 & $309(76.7)$ & $20(4.9)$ & $72(17.9)$ \\
\hline 2 & $\begin{array}{l}\text { I can develop critical thinking } \\
\text { skills by analyzing and } \\
\text { discussing the literary texts }\end{array}$ & 3.53 & .817 & $218(54.1)$ & $39(9.7)$ & $141(35.2)$ \\
\hline 3 & $\begin{array}{l}\text { I can develop the spirit of } \\
\text { community and nationhood by } \\
\text { engaging in literature activities }\end{array}$ & 3.52 & .883 & $214(53.1)$ & $46(11.4)$ & $141(35.2)$ \\
\hline 4 & $\begin{array}{l}\text { I can relate the stories with my } \\
\text { personal life }\end{array}$ & 3.48 & 1.01 & $198(49.2)$ & $59(14.7)$ & $136(33.7)$ \\
\hline 5 & $\begin{array}{l}\text { I am able to learn a range of } \\
\text { cultures than can help broaden } \\
\text { my worldview }\end{array}$ & 4.00 & .862 & $309(77.2)$ & $22(4.60)$ & $70(17.4)$ \\
\hline & Total & 3.69 & .876 & 6194 & 9.06 & 27.84 \\
\hline
\end{tabular}

As depicted in Table 1, a large majority of the students (mean=3.90) can improve their English vocabulary, grammar, and pronunciation through reading literary texts. Besides, a large number of the students (mean=3.53) believe that reading literary texts can improve their critical thinking skills. Most of the students (Mean=3.52) also believe that they can develop the spirit of community and nationhood by engaging in activities in the literature classroom. Almost half 
of the students $(49.2 \%)$ with a mean value of 3.48 believed that they can relate the stories in the literary texts with their personal lives. Besides, a large majority of the students (mean=4.00) amounting to $77.2 \%$ believe that they can learn a range of cultures and other useful insights through reading the literary texts. These findings demonstrate the importance of literature in developing cultural awareness among students. English literature could be an important means of cultural adaptation (Tutyrahiza, 2008; Zhen, 2012).

Further analysis of the findings shows that the students have positive perceptions of the English literature component to a large extent (mean=3.69) in their respective schools. In sum, the students believe that English literature enables them to develop their cultural awareness, critical thinking skills, as well as improve their English grammar and vocabulary. According to Carroli (2002), the students' development of critical awareness is of utmost importance in the process of knowledge acquisition. Besides, the students could relate the literary texts with their personal lives and develop the spirit of community and nationhood. English literature is viewed as a means of improving their language proficiency amongst students (Amer, 2003; Simpson, 2003; Hişmanoğlu, 2005; Keshavarzi, 2012; Paran, 2008). The above findings indicate that English literature could influence learning outcomes and students' personalities. The second research question aims to determine the most preferred literature teaching approaches among the students in the selected secondary schools. Table 2 shows the descriptive statistics for the English literature teaching approaches preferred by the students.

Table 2

Preferred Approaches to the Teaching of English Literature

\begin{tabular}{|c|c|c|c|c|c|c|}
\hline \multirow{2}{*}{\multicolumn{2}{|c|}{ Approaches }} & \multicolumn{5}{|c|}{ Total $(\mathrm{F} / \%)$} \\
\hline & & \multirow{2}{*}{$\frac{\text { Mean }}{3.90}$} & \multirow{2}{*}{$\frac{\text { SD }}{.888}$} & \multirow{2}{*}{$\frac{A+S A}{70.34}$} & \multicolumn{2}{|c|}{$\mathrm{D}+\mathrm{SDN}$} \\
\hline 1 & Information-based approach & & & & 13.30 & 21.32 \\
\hline 2 & Paraphrastic approach & 3.73 & 1.00 & 62.2 & 14.8 & 22.7 \\
\hline 3 & Stylistic approach & 3.66 & .917 & 58.6 & 9.80 & 30.46 \\
\hline 4 & Language-based approach & 3.76 & 0.962 & 64.2 & 11.0 & 24.1 \\
\hline 5 & Personal-Response approach & 3.65 & .962 & 57.8 & 10.0 & 30.9 \\
\hline 6 & Moral-Philosophical approach & 4.13 & .913 & 78.2 & 4.98 & 16.6 \\
\hline
\end{tabular}


As shown in Table 1, the most preferred approach amongst the students is the moral-philosophical approach (mean=4.13), followed by the information-based approach and the language-based approach with mean values of 3.90 and 3.76, respectively. Interestingly, these findings agree with Bridget and Omar's (2007) study which focused on popular teaching approaches amongst teachers of English literature. Similarly, Rashid et al. (2010) found the moral-philosophical approach, which represents the most preferred approach amongst students examined in the present study, to be the second most preferred approach amongst literature teachers. Besides, Hwang and Embi (2007) found the moral-philosophical approach to be the third most preferred approach. The findings reported by Rashid et al. (2010) might be different because the study focused on less proficient students. Therefore, the findings of this study are more consistent with Bridget and Omar's (2007) study which revealed that the moral-philosophical approach was the most preferred.

\section{Discussion}

The findings reported in this study showed that the selected secondary school students have positive perceptions of the English literature component to a large extent. These findings are consistent with most of the previous studies on students' perceptions of literature learning (Carroli, 2002; Naser \& Aziz, 2017; Othman et al., 2015; Tseng, 2010). This evidence could be especially useful in producing positive learning outcomes as presumed in the basic theoretical principles of phenomenography (Åkerlind, 2008; Bussey, Orgill, \& Crippen, 2013; Dahlin, 2007; Runesson, 2005). Also, previous studies demonstrated the importance of looking at the students' perspective to develop and design effective literature teaching approaches (Ahmad \& Aziz, 2009; Carroli, 2002; Sidhu, 2003).

Furthermore, through literary texts, students are exposed to the elements of the target culture (Azmi et al., 2020b; Mengu, 2002). According to the findings of this study, the students believe that English literature enables them to improve their cultural awareness, and this item recorded the highest mean value. In this regard, research shows that English literature could be an important means of cultural adaptation and development of moral values which shape the students' personality (Kow, 2002; Mengu, 2002; Ogunnaike, 2002; Tutyrahiza, 2008; Zhen, 2012). According to Tutyrahiza (2008), exposing students to moral values from the text is a valuable strategy regardless of the students' level of language proficiency. The knowledge acquired through the literature component allows students to appreciate the cultural background and morals which could help them to develop the spirit of 
community and personality (Azmi et al., 2020b; Rahayu, 2009; Velu, 2010).

Moreover, the findings reported in this study showed that the moralphilosophical approach is the most preferred approach amongst the students, followed by the information-based approach and the language-based approach. This information indicates that teachers in the selected secondary schools incorporate moral values in their lessons. The findings of this study are consistent with the study conducted by Bridget and Omar (2007) from the teachers' perspective. Also, the findings are similar to those obtained in most studies focusing on the literature teaching approaches from teachers' perspectives (Hwang \& Embi, 2007; Rashid et al., 2010).

As the literature component was integrated into the EFL syllabus, determining its success could be beneficial to the Ministry of Education (Bridget \& Omar, 2007; Rashid et al., 2010; Savvidou, 2004). Therefore, this study offers important clues to the Ministry of Education concerning the students' level of understanding of the literature component. In turn, this could supplement the effort Curriculum Development Centre toward achieving the best literature learning outcomes. In developing and designing effective teaching approaches, students' involvement in the teaching-learning process is paramount and their positive contributions could result in methodological success (Ahmad \& Aziz, 2009; Timucin, 2001).

\section{Conclusion}

This study examined students' perceptions of the importance of the English literature component in selected Malaysian secondary schools. According to the findings, the students have positive perceptions of the English literature component to a large extent. These positive perceptions foretell the students' achievements and engaged learning of English literature. The study also demonstrated that the knowledge acquired through English literature could enable the students to develop cultural awareness, critical thinking skills, as well as improve their English grammar and vocabulary. Through reading the literary texts, the students could develop their personality and language proficiency. Therefore, teachers of English literature are expected to encourage their students to develop a passion for reading literary texts.

This study is an important contribution to the field of language and literature 
by offering some insightful findings. The study could be beneficial to language and literature instructors as well as education authorities by providing information that could be useful in the process of curriculum development, particularly for secondary schools. Besides, the findings of this study could help educators in selecting appropriate literary texts and teaching approaches to enrich the learning environment. The choice of a suitable approach will further help the students to foster literature reading interests amongst themselves. To this end, there is a need for the proactive role of teachers, governments, and parents. This quantitative study is limited to the importance of the literature component in Malaysian secondary schools from students' perspectives. Further research may adopt a qualitative inquiry to specifically explore the content of the literature reading materials.

\section{Acknowledgements}

This research is funded by the Mentor-Mentee Research Grant (MMRG), Universiti Sultan Zainal Abidin, Malaysia.

\section{Disclosure statement}

No potential conflict of interest was reported by the authors. 


\section{References}

Ahmad, F., \& Aziz, J. (2009). Students' perception of the teachers' teaching of literature communicating and understanding through the eyes of the audience. European Journal of Social Sciences, 7(3), 17-26.

Åkerlind, G. S. (2008). A phenomenographic approach to developing academics' understanding of the nature of teaching and learning. Teaching in Higher Education, 13(6), 633-644.

Allen, M., Titsworth, S. \& Hunt, S. K. (2009). Quantitative research in communication. SAGE Publications.

Alshammari, H. A., Ahmed, E. A., \& Shouk, M. A. A. (2020). Challenges to studying English literature by the Saudi undergraduate EFL students as perceived by instructors. English Language Teaching, 13(3), 8-19.

Amer, A. A. (2003). Teaching EFL/ESL literature. The Reading Matrix, 3(2), 63-73.

Azmi, M. N. L., Hassan, H., Ali, E. M. T. E., Hidayah, A. T., Yah@Alias, M. H., Anas, M., Suhaimi, N. I. (2020a). Teachers' perceptions of Islamic self-identity formation through language learning among students in selected religious secondary schools. International Journal of Society, Culture, and Language, 8(1). Pp: 20-32.

Azmi, M. N. L., Hassan, I., Ali, E. M. T. B. E., Hidayah, A. T., Anas, M. B., \& Suhaimi, N. I. (2020b). English language learning, environment, and the formation of Islamic self-identity among students in selected religious secondary schools. International Journal of Innovation, Creativity, and Change, 11(7), 466482.

Booth, S. (2008, May 5-6). Researching learning in networked learningphenomenography and variation theory as empirical and theoretical approaches [Paper presentation]. The 6th International Conference on Networked Learning, Halkidiki, Greece.

Bridget, L. S. H. , \& Omar, S. (2007, June 14-16). Approaches adopted in the teaching of poetry for the upper secondary school students in Tawau town area [paper presentation]. The Second Biennial International Conference on Teaching and Learning of English in Asia : Exploring New Frontiers. Pahang, Malaysia. 
Bussey, T. J., Orgill, M., \& Crippen, K. J. (2013). Variation theory: A theory of learning and a useful theoretical framework for chemical education research. Chemistry Education Research and Practice, 14(1),9-22.

Candlin, C., \& N. Mercer. (2001). English language teaching in its social context. Routledge.

Carroli, P. (2002). Perceptions of literature: a comparison of students' and educators' views. ELT Journal, 37(1), 30-35.

Carter, R., \& Long, M. (1991). Teaching literature. Longman.

Cheng, K. K. (2016). Issues in the teaching and learning of children's literature in Malaysia. Issues in The Teaching and Learning of Children, 9(2),1-14.

Creswell, J. W. (2012). Research design: Qualitative, quantitative, and mixed-method approaches $\left(2^{\text {nd }}\right.$ ed.). SAGE Publications.

Dahlin, B. (2007). Enriching the theoretical horizons of phenomenography, variation theory and learning studies. Scandinavian Journal of Educational Research, 51(4), 327-346.

Ghazali, S. N., Setia, R., Muthusamy, C., \& Jusoff, K. (2009). ESL students' attitudes towards texts and teaching methods used in literature classes. English Language Teaching, 2(4), 51-56.

Hişmanoğlu, M. (2005). Teaching English through literature. Journal of Language and Linguistic Studies, 1(1), 53-66.

Hwang, D., \& Embi, M. A. (2007). Approaches employed by secondary school teachers to teaching the literature component in English. Malaysian Journal of Educators and Education, 22(3), 1-23.

Ihejirika, R. C. (2014). Literature and English language teaching and learning: A symbiotic relationship". English Language Teaching, 7(3), 85-90.

James A. A. (2012). Media research method: Understanding metric and interpretive approaches ( $1^{\text {st }}$ ed.). SAGE Publications.

Keshavarzi, A. (2012). Use of literature in teaching English". Procedia-Social and Behavioral Sciences, 46(2), 554-559.

Kow, Y. C. (2002). Literacy and pre-school children: Story-telling strategies. Sasbadi. 
Krejcie, R. V., \& Morgan D. W. (1970). Determining sample size for research activities. Educational and Psychological Measurement, 1(30), 607-610.

Krishnasamy, J. (2015). An investigation of teachers' approaches employed in teaching the English literature. Asian Journal of Education and e-Learning, 2(3), 136-145.

Lois H. R., \& Gavin T. L. B. (2010). Mixing interview and questionnaire methods: Practical problems in aligning data. Practical Assessment, Research and Evaluation, 15(1), 1-19.

Mahzan, M. S. W., Alias, N. A., \& Ismail, I. S. (2020). Investigating the needs of developing a digital vocabulary learning material for Malaysian indigenous learners in ESL Classroom. Journal of Nusantara Studies (JONUS), 5(2), 282302.

Marton, F., \& Booth, S. (1997). Learning and awareness. Lawrence Erlbaum Associates.

Marton, F., \& Tsui, A. (Ed.). (2004). Classroom discourse and the space of learning. Lawrence Erlbaum Associates.

Mengu, H.I. (2002). A suggested syllabus for the drama teaching course in ELT departments (Unpublished Master's thesis). Hacettepe University.

Mustafa, T., Kawther, P., \& Rashid, S. (2020). Investigation of Kurdish students' perceptions of using literature as main material in the EFL speaking course. Journal of Tikrit University for Humanities, 27(5), 88-62.

Mustakim, S. S., Mustafa, R., \& Lebar, O. (2015). Critical analysis of the supportive and suppressive factors. Journal of Education and Learning, 2(6), 1-10.

Naser, S. H. M., \& Aziz, A. A. (2017, August 23). Students' perceptions of the text selection in the literature component [Paper presentation]. The National PreUniversity Seminar, Selangor, Malaysia.

Ogunnaike, J. (2002). Challenges of the teaching and learning of literature in Nigerian secondary schools. In I. Lawal \& I. N. Ohia (Eds.), Perspectives on applied linguistics in language and literature (pp. 307-320). Stirling-Horden Publishers.

Othman, N. I., Shah, P. M., Karim, A. A., Yusof, A., Din, R., Ramli, N. A., \& Salleh, N. S. M. (2015). Personalizing learning of English literature: Perceptions and 
challenges. Journal of Personalized Learning, 1(1), 104-112.

Paran, A. (2008). The role of literature in instructed second language learning and teaching: An evidence-based survey. Language Teaching, 41(4), 465-496.

Rashid, R. A., Vethamani, M. E., \& Rahman, S. B. A. (2010). Approaches employed by teachers in teaching literature to less proficient students in Form 1 and Form 2. English Language Teaching, 3(4), 87-99.

Runesson, U. (2005). Beyond discourse and interaction. Variation: A critical aspect for teaching and learning mathematics. Cambridge Journal of Education, 35(1), 69-87.

Sarac, S. (2003). A suggested syllabus for the teaching of poetry course in ELT departments of Turkey (Unpublished Master's thesis). Hacettepe University.

Savvidou, C. (2004). An integrated approach to teaching literature in the EFL classroom. The Internet TESL Journal, 10(12), 1-6.

Sidhu, G. K. (2003). Literature in the language classroom: Seeing through the eyes of learners. In G. Subramaniam (Ed.), Teaching of literature in ESL/EFL contexts (pp. 187-206). Sasbadi.

Simpson, P. (2003). Language through literature: An introduction. Routledge.

Subramaniam, G. (2007). Literature programme in Malaysian schools: Then and now. Teaching English in Malaysia, 1(1), 50-62.

Svensson, L. (1997). Theoretical foundations of phenomenography. Higher Education Research \& Development, 16(2), 159-171.

Tan, K. (2009). Variation theory and the different ways of experiencing educational policy. Educational Research for Policy and Practice, 8(2), 95-109.

Tavakol, M., \& Dennick, R. (2011). Post-examination analysis of objective tests. Medical Teacher, 33(6), 447-458.

Timucin, M. E. T. I. N. (2001). Gaining insight into alternative teaching approaches employed in an EFL literature class. Revista de Filología y su Didáctica, 24 (1), 269-293.

Tseng, F. P. (2010). Introducing literature to an EFL classroom: Teacher's presentations and students' perceptions. Journal of Language Teaching and Research, 1(1), 53-65. 
Tutyrahiza, M. (2008). Teaching reading strategies used by ESL teachers that facilitate teaching and learning reading (Unpublished Master's Thesis). University Malaysia Sarawak.

Van, T. T. M. (2009). The relevance of literary analysis to teaching literature in the EFL classroom. English Teaching Forum, 47(3), 2-17.

Velu, J. (2010). Psychometric analysis of lecturers' self-efficacy instrument. HERDSA Annual International, 2(3), 65-96.

Zengin, B., Başal, A., \& Yükselir, C. (2019). Investigation into the perceptions of English teachers and instructors on the use of literature in English language teaching. The Reading Matrix, 19(1), 155-166.

Zhen, Z. (2012). Characteristics and strategies of literature teaching in the EFL context in China. International Journal of Electronics and Communication Engineering, 5 (3), 35-43.

\begin{abstract}
About the Authors
${ }^{1}$ Engku Suhaimi Engku Atek is a Lecturer of English Language in the Faculty of Languages and Communication, Universiti Sultan Zainal Abidin (UniSZA), Malaysia. He holds a Master's degree in English Language Studies. Engku Suhaimi is an active researcher in the areas of English literature teaching and learning, language literacy, and cultural communication.
\end{abstract}

2 Isyaku Hassan is a Postdoctoral Researcher in the Faculty of Languages and Communication, Universiti Sultan Zainal Abidin (UniSZA), Malaysia. He specializes in media linguistics. Isyaku holds a $\mathrm{PhD}$ in Communication. His area of research interest includes Language, Communication, and Literary Studies.

${ }^{3}$ Mohd Nazri Latiff Azmi is an Associate Professor of English Language in the Faculty of Languages and Communication, Universiti Sultan Zainal Abidin (UniSZA), Malaysia. Mohd Nazri holds a PhD in Literature and Literacy. He is a former Dean and Head of English Department in the Faculty of Languages and Communication, UniSZA. Mohd Nazri specializes in Literacy and Comparative Literature Studies.

4 Nor Jijidiana Azmi is a Lecturer of English Language in the Faculty of Languages and Communication, Universiti Sultan Zainal Abidin (UniSZA), Malaysia. Jijidiana has a keen interest in research activities, particularly in the 
area of marketing communication, public relations, media studies, and language literacy.

5 Mohd Hazli Yah Alias is a Lecturer of Arabic Language in the Faculty of Languages and Communication, Universiti Sultan Zainal Abidin (UniSZA), Malaysia. Mohd Hazli teaches Arabic as a Foreign Language (AFL), Language Acquisition, and Language Literacy. His area of research interest includes Language Learning and Literary Analysis. 